\title{
Sensitization to Self (Virus) Antigen by In Situ Expression of Murine Interferon- $\gamma$
}

Myung-Shik Lee, Matthias von Herrath, Hans Reiser," Michael B. A. Oldstone, and Nora Sarvetnick

Department of Neuropharmacology, The Scripps Research Institute, La Jolla, California 92037; and *Department of Pathology, Harvard Medical School, Boston, Massachusetts 02115

\begin{abstract}
Autoimmune disease results from inflammatory destruction of tissues by aberrant self-reactive lymphocytes. We studied the autoimmune potential of $T$ lymphocytes immunologically ignorant of viral antigens acting as self antigens and whether the host defense molecule IFN- $\boldsymbol{\gamma}$ could stimulate these cells to cytotoxic competency. For this purpose, we produced double transgenic mice expressing pancreatic IFN- $\gamma$ as well as lymphocytic choriomeningitis virus (LCMV) nucleoprotein (NP) or glycoprotein (GP) antigen. $100 \%$ of the $\mathrm{NP}^{+} / \mathrm{IFN}-\boldsymbol{\gamma}^{+}$mice became diabetic before 2 mo of age, while none of the NP single transgenic littermates and only $10 \%$ of IFN- $\gamma$ single transgenic littermates did. Strikingly, $\mathrm{NP}^{+} / \mathrm{IFN}-\boldsymbol{\gamma}^{+}$mice spontaneously developed cytotoxic $T$ lymphocyte activity on LCMV-infected targets and vaccinia virus-NP-infected ones without prior LCMV infection but $\mathrm{NP}^{+} / \mathrm{IFN}-\boldsymbol{\gamma}^{-}$mice did not, which indicates specific sensitization to the viral antigen by IFN- $\gamma$. These results suggest that lymphocytes ignorant of self antigens can be activated by IFN- $\gamma$ released after immunologic stimulation such as viral infection. This mechanism may account for the loss of apparent tolerance to self antigens in autoimmune diseases such as insulin-dependent diabetes mellitus. ( $J$. Clin. Invest. 1995. 95:486-492.) Key words: autoimmunity - transgenic mice • pancreatic islets • diabetes • B7-1
\end{abstract}

\section{Introduction}

The question of how a pathogenic autoimmune response develops has been of interest to immunologists and clinicians for many years. In many autoimmune diseases, sensitized and activated autoreactive $\mathrm{T}$ lymphocytes destroy target cells harboring the corresponding tissue-specific antigens. In insulin-dependent diabetes mellitus patients, circulating autoreactive $T$ lymphocytes that respond to the islet/brain antigen glutamic acid decarboxylase have been demonstrated (1-3). If an understanding of the events that cause these lymphocytes to become sensitized to antigens such as glutamic acid decarboxylase could be at-

Address correspondence to Nora Sarvetnick, Department of Neuropharmacology, CVN-10, The Scripps Research Institute, 10666 North Torrey Pines Road, La Jolla, CA 92037. Phone: 619-554-7066; FAX: 619-5546477.

Received for publication 19 July 1994 and in revised form 20 September 1994.

J. Clin. Invest.

(C) The American Society for Clinical Investigation, Inc.

0021-9738/95/02/0486/07 \$2.00

Volume 95, February 1995, 486-492 tained, then development of preventative treatment for autoimmune diseases might follow.

To study this process of lymphocyte sensitization in insulindependent diabetes mellitus, we initially addressed the consequences of targeted expression of the host defense molecule IFN- $\gamma$ in the pancreatic islets (Ins-IFN- $\gamma$ mice) $(4,5)$. These studies demonstrated that islet expression of IFN- $\gamma$ does lead to immunological sensitization to whole pancreatic islets, however, the target antigen was not identified, and thus the mechanism of autoimmunity could not be studied. Specifically, it is not known whether sequestered antigens within islets are encountered by lymphocytes for the first time after islet damage or whether circulating cells within the normal repertoire become activated to destroy their target when they are in contact with the IFN in the pancreas.

To address these mechanistic issues, we used transgenic mice that express lymphocytic choriomeningitis virus (LCMV) ${ }^{1}$ antigen on their pancreatic $\beta$ cells (RIP-LCMV mice) to provide a unique tissue-specific antigen toward which the cell-mediated and humoral immune responses can be monitored. The RIPLCMV transgenic mice are normoglycemic and free of insulitis; however, they develop autoimmune diabetes when infected with LCMV $(6,7)$. These results suggested that lymphocytes that could react to peripheral self antigens are not deleted but have never encountered these antigens because of their location on non-antigen-presenting cells (APC). It is possible that the activation of such $\mathrm{T}$ cells specific for self antigens may be mediated via inflammatory cytokines elicited by viral infection.

To determine whether $\mathrm{T}$ cells that had never encountered self antigens could be activated by inflammatory cytokines, we crossed Ins-IFN- $\gamma$ mice with RIP-LCMV mice. LCMV antigen was in the form of either the viral glycoprotein (GP) or nucleoprotein (NP). The incidence of spontaneous diabetes, histopathology, and anti-viral cytotoxic T lymphocyte (CTL) responses were studied. Strikingly, we observed the spontaneous generation of CTL specific for self (viral) antigen in double transgenic mice but not in LCMV single transgenic littermates. Since LCMV-specific T cells would be present in both the double and single transgenic mice $(6,7)$, our data suggest that IFN- $\gamma$ can induce the development of CTL from circulating T lymphocytes within the repertoire of a normal individual.

\section{Methods}

Double transgenic mice. The Ins-IFN- $\gamma$ murine line was maintained by repeated crossings with BALB/c mice. RIP-LCMV-GP mice (line 34-

1. Abbreviations used in this paper: APC, antigen-presenting cell; CTL, cytotoxic T lymphocyte; LCMV, lymphocytic choriomeningitis virus; $\mathrm{NP}$, nucleoprotein; VV, vaccinia virus. 
Table I. Incidence of Spontaneous Diabetes* in LCMV/IFN- $\gamma$ Double Transgenic Mice

\begin{tabular}{lcccl}
\hline & Both $^{+}$ & $\begin{array}{c}\mathrm{NP}^{+} \text {or GP } \\
\text { only }\end{array}$ & $\begin{array}{c}\text { IFN- } \gamma^{+} \\
\text {only }\end{array}$ & Both $^{-}$ \\
\hline LCMV-NP/IFN- $\gamma$ & $13 / 13^{\ddagger}$ & $0 / 6$ & $1 / 10$ & $0 / 10$ \\
LCMV-GP/IFN- $\gamma$ & $2 / 9$ & $0 / 7$ & $4 / 9$ & $0 / 9$
\end{tabular}

* Diabetes was confirmed by a glucose level of $>300 \mathrm{mg} / \mathrm{dl}$ in monthly determinations of ocular blood samples over the 4-mo observation period. ${ }^{\ddagger}$ The incidence of diabetes in $\mathrm{NP}^{+} / \mathrm{IFN}-\gamma^{+}$mice was significantly higher than that in all other groups of mice $(P<0.005)$.

20) were selected from those maintained by repeated crossings to C57BL/6. Ins-IFN- $\gamma$ mice were intercrossed to RIP-LCMV-NP (line 25-3) or RIP-LCMV-GP mice to derive lines positive for both transgenes. F1 mice were screened by PCR amplification of genomic DNA. NP-specific primers were CAGTTATAGGTGCTCTTCCGC and AGATCTGGGAGCCTTGCTTTG. GP-specific primers were CGCCGGTCTTTGCATGTTCTAG and GCACATTCACCTGGACTTTGTC. Primers for human insulin promoter sequences were CCTGGTCTAATGTGGAAAGTG and TGCAATTTCCGGACCATTTCC. 20 $\mu \mathrm{g} / \mathrm{ml}$ tail DNA, $1 \mu \mathrm{M}$ each primer, $200 \mu \mathrm{M}$ each deoxynucleoside triphosphate, $2 \mathrm{mM} \mathrm{MgCl}$, and $40 \mathrm{U} / \mathrm{ml} T a q$ polymerase were mixed for PCR. Annealing and polymerization were done at 60 and $72^{\circ} \mathrm{C}$, respectively, for a total of 25 cycles. The incidence of spontaneous diabetes in F1 mice was determined by monthly determination of blood glucose level over the 4-mo observation period. In some mice, weekly measurement of blood glucose level was done. Diabetes was confirmed by a glucose level of $>300 \mathrm{mg} / \mathrm{dl}$ in ocular blood samples tested with a Glucometer 3 (Miles Inc., Elkhart, IN).

Immunohistochemistry. Fresh-frozen sections of the pancreatic tissue were incubated with anti-CD4 (PharMingen, San Diego, CA), anti-CD8 (PharMingen), anti-B220 (PharMingen), anti-Mac-1 (Boehringer Mannheim, Indianapolis, IN), F4/80 (Serotec Ltd., Kidlington, Oxford, United Kingdom), or anti-B7-1 antibody (8) for $30 \mathrm{~min}$ at room temperature. The concentration of primary mAbs was between 5 and $10 \mu \mathrm{g} /$ $\mathrm{ml}$. Incubations with biotinylated secondary antibody and then with avidin-biotin-peroxidase complex followed for $30 \mathrm{~min}$ each. After the color reaction with diaminobenzidine, the sections were counterstained in hematoxylin solution or methyl green for histopathologic examination. We evaluated 15-30 islets from 2-3 histological sections of each mouse.

Double immunofluorescence. Fresh-frozen sections of pancreatic tissue were incubated with either one of anti-B220, anti-Mac-1, or F4/80 antibody followed by incubation with tetramethylrhodamine isothiocyanate (TRITC)-labeled anti-rat IgG for $30 \mathrm{~min}$ at room temperature. They were sequentially incubated with anti-B7-1 antibody and then FITC-labeled anti-hamster IgG for $30 \mathrm{~min}$, respectively. Control experiments using one of the primary antibodies and an irrelevant one of the two secondary antibodies were performed and confirmed the specificity of our results.

$C T L$ response. Secondary CTL activity was measured as previously described (9). Splenocytes and PBL were cultured for $>1 \mathrm{wk}$ on macrophage-coated plates that were infected with LCMV Armstrong at a moi of 1 and then irradiated 2,000 rad. These macrophages had been harvested $3 \mathrm{~d}$ after intraperitoneal injection of $3.85 \%$ thioglycolate. BALB C1.7 (H-2 $\left.2^{d}\right)$ or MC57 (H-2 $\left.{ }^{b}\right)$ targets were infected with LCMV Armstrong at a moi of 1 or with vaccinia virus (VV)-NP (or VV-GP) at a moi of 3. Uninfected target cells were used as controls. All cells were labeled with ${ }^{51} \mathrm{Cr}$ and incubated with stimulated lymphocytes at various $\mathrm{E} / \mathrm{T}$ ratios. Lymphocytes from BALB/c or C57BL/6 mice infected with $2 \times 10^{5}$ plaque forming units of LCMV Armstrong served as positive controls.

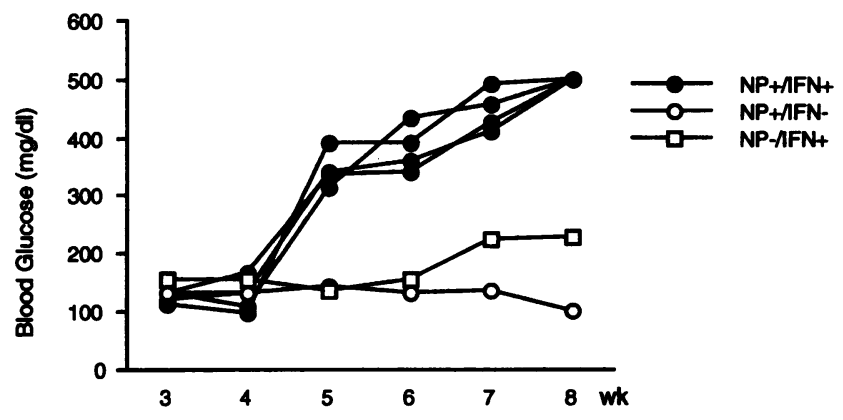

Figure 1. Weekly blood glucose determination in four $\mathrm{NP}^{+} / \mathrm{IFN}-\gamma^{+}$ mice. All NP $/$ IFN $-\gamma^{+}$mice became diabetic $(>300 \mathrm{mg} / \mathrm{dl}$ ) between 5 and $6 \mathrm{wk}$ with wasting. One NP-/IFN- $\gamma^{+}$mouse and one $\mathrm{NP}^{+} / \mathrm{IFN}-\gamma^{-}$ mouse were not diabetic although the former showed mild hyperglycemia. Blood glucose level of $500 \mathrm{mg} / \mathrm{dl}$ at $8 \mathrm{wk}$ of age means $>500$ $\mathrm{mg} / \mathrm{dl}$.

ELISA of anti-LCMV antibody. Humoral immune response to LCMV protein was assayed using an ELISA according to a modification of previously described methods (9). After coating each well of 96-well plates with $1 \mu \mathrm{g}$ of LCMV antigen and blocking with $10 \%$ bovine serum/0.2\% Tween 20 , serial dilutions of serum from $1: 10$ to $1: 1,000$ were added, and incubation was done for $1 \mathrm{~h}$ at room temperature. After washing, peroxidase-conjugated antimurine IgG was added. Subsequently, substrate solution containing $o$-phenylene diamine (Sigma Immunochemicals, St. Louis, MO) was added, and absorption at $492 \mathrm{~nm}$ was measured.

Statistical analysis. The $\mathrm{Z}$ test was used to compare the incidence of spontaneous diabetes between groups.

\section{Results}

Development of diabetes. To characterize the islet function in double and single transgenic mice, we initially measured the blood glucose levels. All of $13 \mathrm{NP}^{+} / \mathrm{IFN}-\gamma^{+}$double transgenic mice became diabetic, but none of $6 \mathrm{NP}^{+} / \mathrm{IFN}-\gamma^{-}$and only 1 of $10 \mathrm{NP}^{-} / \mathrm{IFN}-\gamma^{+}$mice became diabetic over the 4-mo observation period (Table I). In contrast, two of nine $\mathrm{GP}^{+} / \mathrm{IFN}-\gamma^{+}$ double transgenic mice became diabetic, whereas none of seven $\mathrm{GP}^{+} / / \mathrm{IFN}-\gamma^{-}$and four of nine GP $/$IFN $-\gamma^{+}$littermates became diabetic (Table I). The incidence of diabetes in $\mathrm{NP}^{+} / \mathrm{IFN}-\gamma^{+}$ mice was significantly higher than that in $\mathrm{NP}^{-} / \mathrm{IFN}-\gamma^{+}$or $\mathrm{GP}^{+} /$ IFN- $\gamma^{+}$mice (both $P<0.005$ ); however, the incidence of diabetes in $\mathrm{GP}^{+} / \mathrm{IFN}-\gamma^{+}$was not significantly different from that in $\mathrm{GP}^{-} / \mathrm{IFN}-\gamma^{+}$mice $(P>0.1)$. All NP ${ }^{+} / \mathrm{IFN}-\gamma^{+}$double transgenic mice became diabetic before 2 mo of age on the basis of monthly blood glucose determination. Weekly blood glucose levels on mice from typical litters showed that all four $\mathrm{NP}^{+} / \mathrm{IFN}-\gamma^{+}$double transgenic mice became diabetic between 5 and $6 \mathrm{wk}$ of age (Fig. 1). In addition, all $\mathrm{NP}^{+} / \mathrm{IFN}-\gamma^{+}$mice showed emaciation at the age of 2 mo. These suggested that probably all $\mathrm{NP}^{+} / \mathrm{IFN}-$ $\gamma^{+}$double transgenic mice became diabetic before $6 \mathrm{wk}$ of age. The other three kinds of mice (NP- $/ \mathrm{IFN}-\gamma^{+}, \mathrm{GP}^{+} / \mathrm{IFN}-\gamma^{+}$, and $\left.\mathrm{GP}^{-} / \mathrm{IFN}-\gamma^{+}\right)$developed diabetes after 2 mo of age.

Histology of the pancreas. Histopathological studies of the NP or GP single transgenic littermates $(n=4$ each) revealed no pancreatic inflammation; however, in both $\mathrm{NP}^{+} / \mathrm{IFN}-\gamma^{+}(n$ $=5)$ and $\mathrm{GP}^{+} / \mathrm{IFN}-\gamma^{+}(n=4)$ double transgenic mice as well as IFN- $\gamma$ single transgenic mice $(n=2)$ at the age of $2-5 \mathrm{mo}$, 

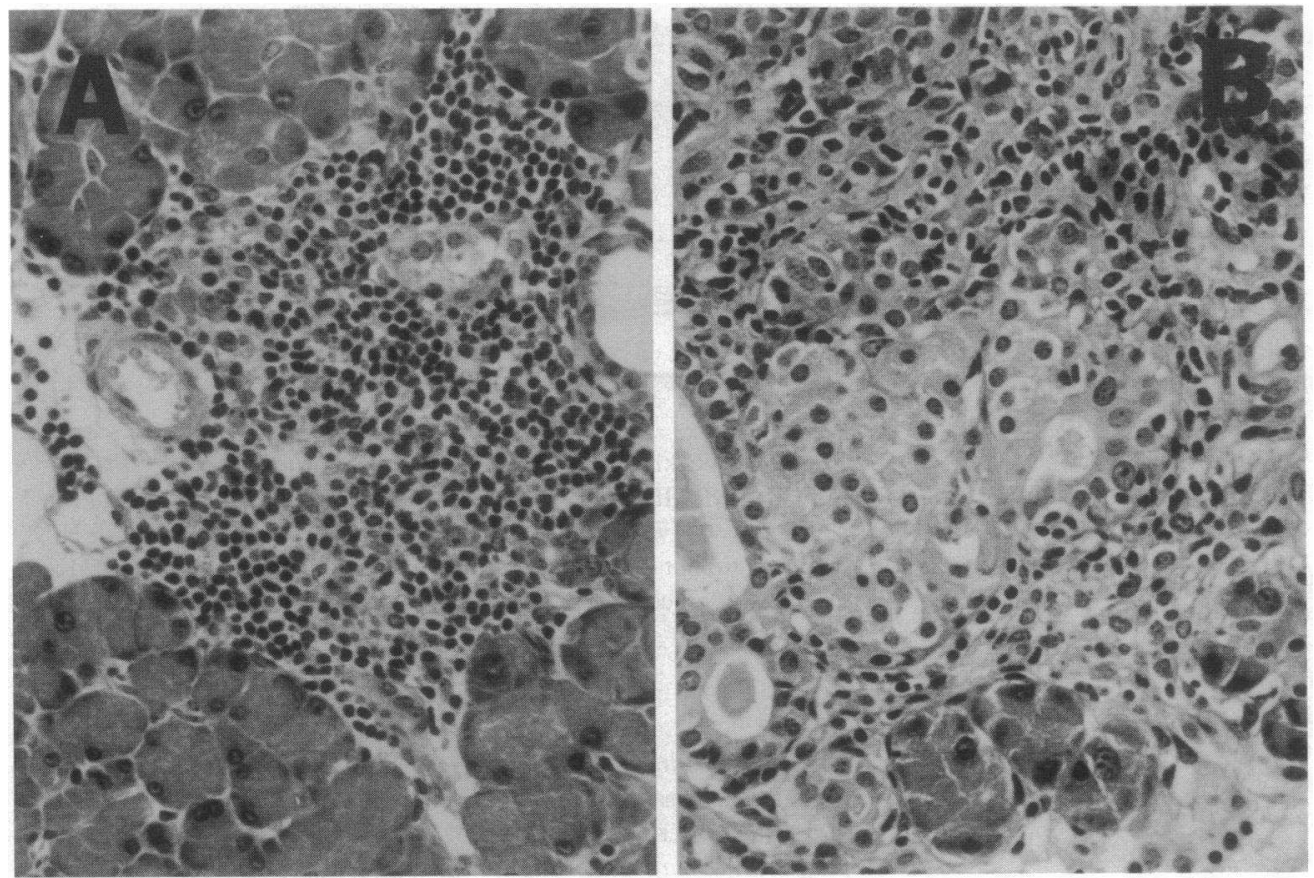

Figure 2. Histopathology of the double transgenic mice. $(A)$ The pancreas from a 4-mo-old $\mathrm{NP}^{+}$I IFN- $\gamma^{+}$mouse showed infiltration of mononuclear cells into the islets that were almost completely destroyed $(\times 400)$. $(B)$ The pancreas from a 4-mo-old $\mathrm{GP}^{+} / \mathrm{IFN}-\gamma^{+}$ mouse showed mononuclear cell infiltration of similar pattern with remaining islet tissue $(\times 400)$

mononuclear cell infiltration into the islets was documented with islet destruction of variable degree (Fig. 2, $A$ and $B$ ). Immunohistochemical studies showed that infiltrating cells comprised macrophages stained with anti-Mac-1 or F4/80, $\mathrm{CD}^{+}{ }^{+}$or $\mathrm{CD} 8^{+}$ $\mathrm{T}$ lymphocytes, and also B lymphocytes stained with anti-B220 in both $\mathrm{NP}^{+} / \mathrm{IFN}-\gamma^{+}$and $\mathrm{GP}^{+} / \mathrm{IFN}-\gamma^{+}$double transgenic mice at the age of 2-4 mo $(n=3$ each) and in a 3-mo-old IFN- $\gamma$ single transgenic littermate $(n=1)$ (Fig. $3, A-D)$. We estimated that $\mathrm{CD}^{+} \mathrm{T}$ lymphocytes and $\mathrm{CD} 8^{+} \mathrm{T}$ lymphocytes accounted for 65 and $15 \%$ of total infiltrating cells, respectively, whereas macrophages and B lymphocytes each represented $10 \%$ of the infiltrating cells.

Spontaneous generation of CTL against self (viral) antigens. To determine if lymphocytes from $\mathrm{NP}^{+} / \mathrm{IFN}-\gamma^{+}$or $\mathrm{GP}^{+} / \mathrm{IFN}-\gamma^{+}$ mice could be specifically sensitized to LCMV antigen without LCMV infection, secondary CTL assays were performed. These studies revealed that lymphocytes from three $\mathrm{NP}^{+} / \mathrm{IFN}-\gamma^{+}$mice tested killed 20,30 , and $41 \%$ of LCMV-infected target cells at
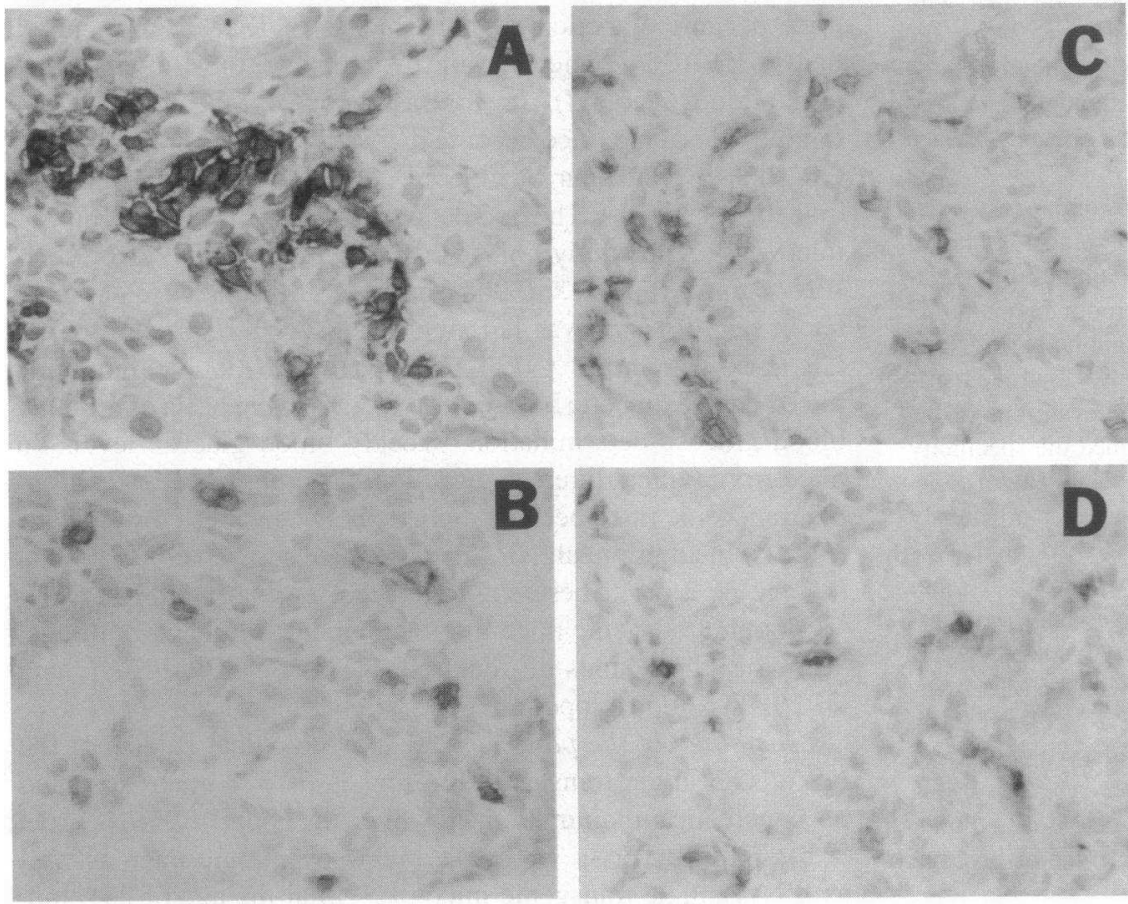

Figure 3. Immunohistochemical staining of the double transgenic pancreas. $(A) \mathrm{CD}^{+}$lymphocytes in the pancreas of a 3 -mo-old NP $\mathrm{N}^{+} / \mathrm{IFN}$ $\gamma^{+}$mouse; $(B) \mathrm{CD}^{+}$lymphocytes in the pancreas of the $\mathrm{NP}^{+} / \mathrm{IFN}-\gamma^{+}$mouse; $(C) \mathrm{CD}^{+}$lymphocytes in the pancreas of a 3-mo-old $\mathrm{GP}^{+} /$ IFN- $\gamma^{+}$mouse; and $(D) \mathrm{CD}^{+}$lymphocytes in the pancreas of the $\mathrm{GP}^{+} / \mathrm{IFN}-\gamma^{+}$mouse. B lymphocytes stained with anti-B220 and Mac-1positive macrophages were also observed in both $\mathrm{NP}^{+} / \mathrm{IFN}-\gamma^{+}$and $\mathrm{GP}^{+} / \mathrm{IFN}-\gamma^{+}$double transgenic pancreata. 

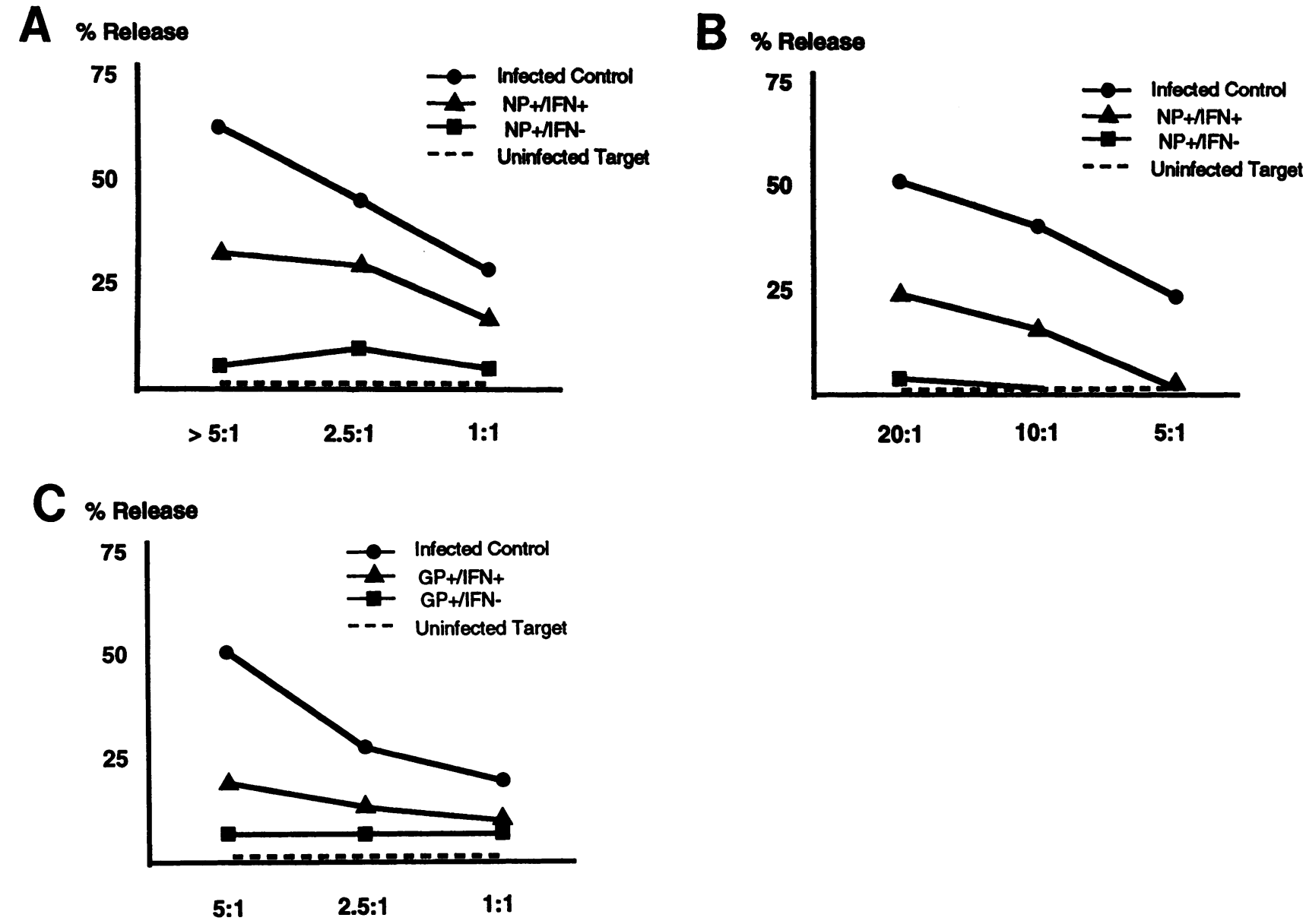

Figure 4. Secondary CTL response to LCMV antigens in double transgenic mice and single transgenic littermates used as controls. Lymphocytes from $\mathrm{NP}^{+} / \mathrm{IFN}-\gamma^{+}$mice killed both LCMV-infected $(A)$ and VV-NP-infected targets $(B)$ to a moderate degree, whereas lymphocytes from $\mathrm{NP}^{+} /$ IFN- $\gamma^{-}$mice exerted only negligible killing of these targets $(A$ and $B)$. Lymphocytes from GP ${ }^{+} /$FFN- $\gamma^{+}$mice killed a small portion of LCMVinfected targets $(C)$. Lymphocytes from LCMV-infected mice used as positive controls showed strong CTL response to LCMV antigens $(A-C)$.

an $\mathrm{E} / \mathrm{T}$ ratio of 5 or more (Fig. $4 \mathrm{~A}$ ). To further characterize the CTL response, we used VV-NP-infected target cells instead of LCMV-infected targets. Lymphocytes from $\mathrm{NP}^{+} / \mathrm{IFN}-\gamma^{+}$ mice killed 17,19 , and $31 \%$ of VV-NP-infected targets but no VV-GP-infected targets or uninfected cells (Fig. 4 B). Lymphocytes from three $\mathrm{GP}^{+} / \mathrm{IFN}-\gamma^{+}$nondiabetic mice killed 12,14 , and $22 \%$ of the LCMV-infected targets at an E/T ratio of 5 but not uninfected targets (Fig. $4 \dot{C}$ ). $\mathrm{CTL}$ response of $\mathrm{GP}^{+} / \mathrm{IFN}$ $\gamma^{+}$mice was not characterized further.

In contrast to CTL response, the humoral response to LCMV antigens was not detected in double transgenic mice. Sera from five $\mathrm{NP}^{+} / \mathrm{IFN}-\gamma^{+}$, two $\mathrm{GP}^{+} / \mathrm{IFN}-\gamma^{+}$, one $\mathrm{NP}^{+} / \mathrm{IFN}-\gamma^{-}$, and one $\mathrm{GP}^{+} / \mathrm{IFN}-\gamma^{-}$mice did not show any antibody activity in an ELISA test up to 1:10 dilution, whereas sera from LCMVinfected mice showed strong antibody activity even at 1:1,000 dilution.

Expression of costimulatory molecules. Activation or sensitization of naive $\mathrm{T}$ cells depends critically on the recognition of costimulatory signals. We histochemically examined the expression of B7-1, a membrane-bound costimulatory molecule expressed by APC (10). We found that B7-1 was expressed on infiltrating cells in the pancreas of $\mathrm{NP}^{+} / \mathrm{IFN}-\gamma^{+}$and $\mathrm{GP}^{+} / \mathrm{IFN}$ - $\gamma^{+}$double transgenic mice at the age of $2-4$ mo $(n=3$ each $)$ as well as in a 3-mo-old IFN- $\gamma$ single transgenic mouse but not on pancreatic parenchymal cells (Fig. 5, $A-C$ ). Additionally, double immunofluorescence studies disclosed that B7-1 molecules were expressed on macrophages and B lymphocytes in the pancreata of $\mathrm{NP}^{+} / \mathrm{IFN}-\gamma^{+}$and $\mathrm{GP}^{+} / \mathrm{IFN}-\gamma^{+}$double transgenic mice (Fig. 6, $A-D$ ).

\section{Discussion}

We observed a very high incidence of diabetes in $\mathrm{NP}^{+} / \mathrm{IFN}-\gamma^{+}$ mice with accelerated onset, while that in $\mathrm{GP}^{+} / \mathrm{IFN}-\gamma^{+}$mice was not different from IFN- $\gamma^{+}$single transgenic littermates. The incidence of early onset diabetes was high in the initial generations of Ins-IFN- $\gamma$ mice (4) but gradually decreased to $30-40 \%$ in males and $0-10 \%$ in females after repeated crossing with BALB/c (Lee, M.-S., et al., unpublished data). This change appeared to be caused by a shift in the balance between destruction and regeneration of islet cells $(11,12)$. The incidence of diabetes in $\mathrm{NP}^{-} / \mathrm{IFN}-\gamma^{+}, \mathrm{GP}^{-} / \mathrm{IFN}-\gamma^{+}$, and $\mathrm{GP}^{+} / \mathrm{IFN}-\gamma^{+}$mice is consistent with those recent observations. However, that $100 \%$ of $\mathrm{NP}^{+} / \mathrm{IFN}-\gamma^{+}$mice spontaneously developed diabetes 

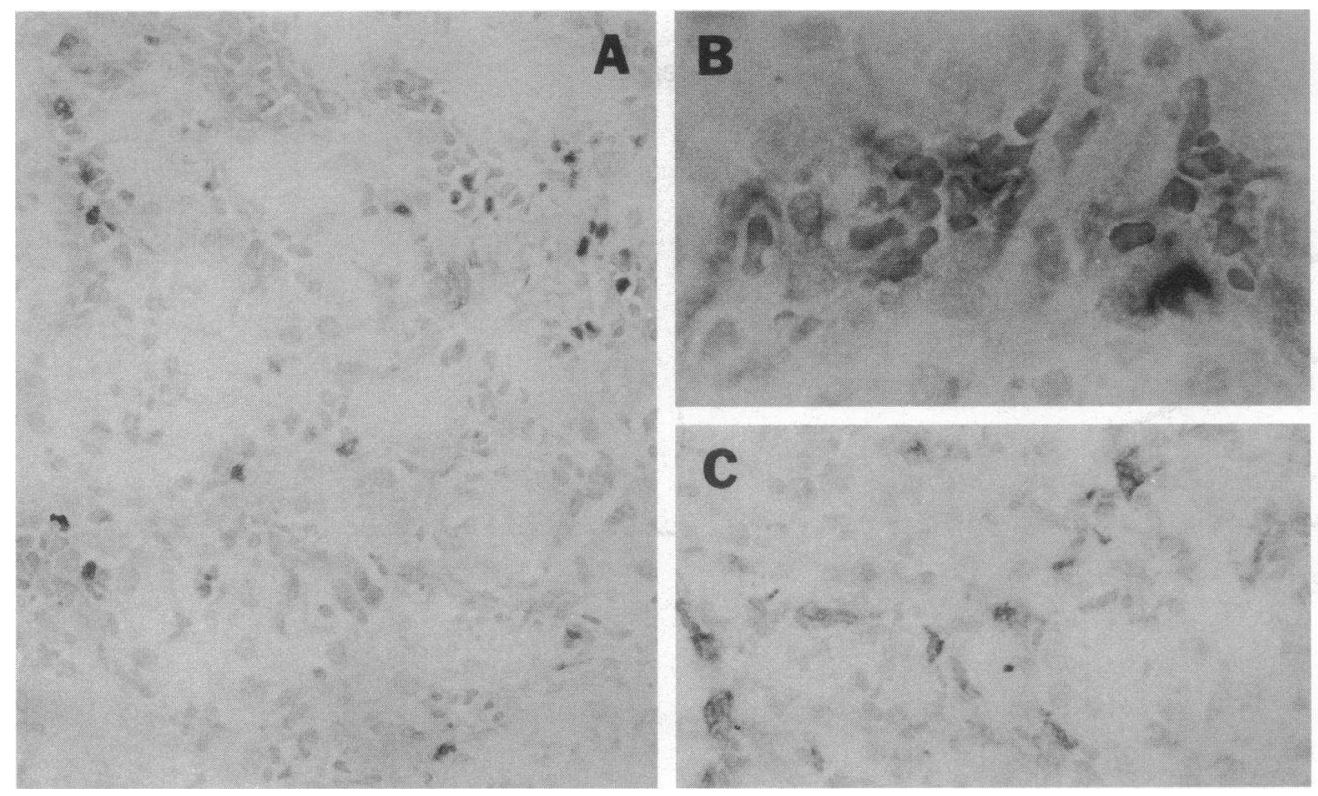

Figure 5. Expression of B7-1 molecules. Immunohistochemical staining disclosed that B7-1 molecules were expressed on infiltrating cells but not on islets or other parenchymal cells in the pancreata of a 3-mo-old NP ${ }^{+} / \mathrm{IFN}-\gamma^{+}$mouse (A) $(\times 400)$ and a 3-mo-old $\mathrm{GP}^{+} /$ IFN- $\gamma^{+}$mouse $(B)(\times 1,000)$. Infiltrating cells in the pancreata of a 3-mo-old IFN- $\gamma$ single transgenic mouse also expressed B7-1 molecules $(C)(\times 400)$. represents a significantly increased incidence compared with other mice.

We demonstrated the spontaneous generation of CTL against self antigens (LCMV) in our LCMV/IFN- $\gamma$ double transgenic mice but not in LCMV single transgenic littermates. These CTL were observed both in NP+ $/ \mathrm{IFN}-\gamma^{+}$mice and to a lesser degree in $\mathrm{GP}^{+} / \mathrm{IFN}-\gamma^{+}$mice. The less robust $\mathrm{CTL}$ response of $\mathrm{GP}^{+} / \mathrm{IFN}-\gamma^{+}$mice to LCMV-infected targets and their lower incidence of diabetes compared with $\mathrm{NP}^{+} / \mathrm{IFN}-\gamma^{+}$mice are almost certainly explained by MHC restriction of lymphocyte-mediated cytotoxicity and gene dosage effects. GP ${ }^{+} / \mathrm{IFN}-$ $\gamma^{+}$mice have a b $\times d$ MHC haplotype. The GP antigen of LCMV can be presented to CTL on $\mathrm{H}-2^{\mathrm{b}}$ but not on $\mathrm{H}-2^{\mathrm{d}}$ mole- cules, whereas the NP antigen is recognized by such cells on both $\mathrm{H}-2^{\mathrm{b}}$ and $\mathrm{H}-2^{\mathrm{d}}$ molecules (13). The incidence of diabetes even after LCMV infection of GP single transgenic mice of $b$ $\times d$ MHC haplotype was only $33 \%$ (3/9) over the 4-mo observation period, although all mice developed positive antibody responses to the LCMV antigen indicating successful LCMV infection (14). The difference in the incidence of diabetes between $\mathrm{NP}^{+} / \mathrm{IFN}-\gamma^{+}$and $\mathrm{GP}^{+} / \mathrm{IFN}-\gamma^{+}$mice underscores the differing abilities of individual antigens to elicit immune responses, and the very high incidence of diabetes in $\mathrm{NP}^{+} / \mathrm{IFN}-\gamma^{+}$mice could be attributed to the presence of a single antigen that can be effectively recognized by CTL. Besides the gene dosage effect, different expression levels between NP and GP target antigens
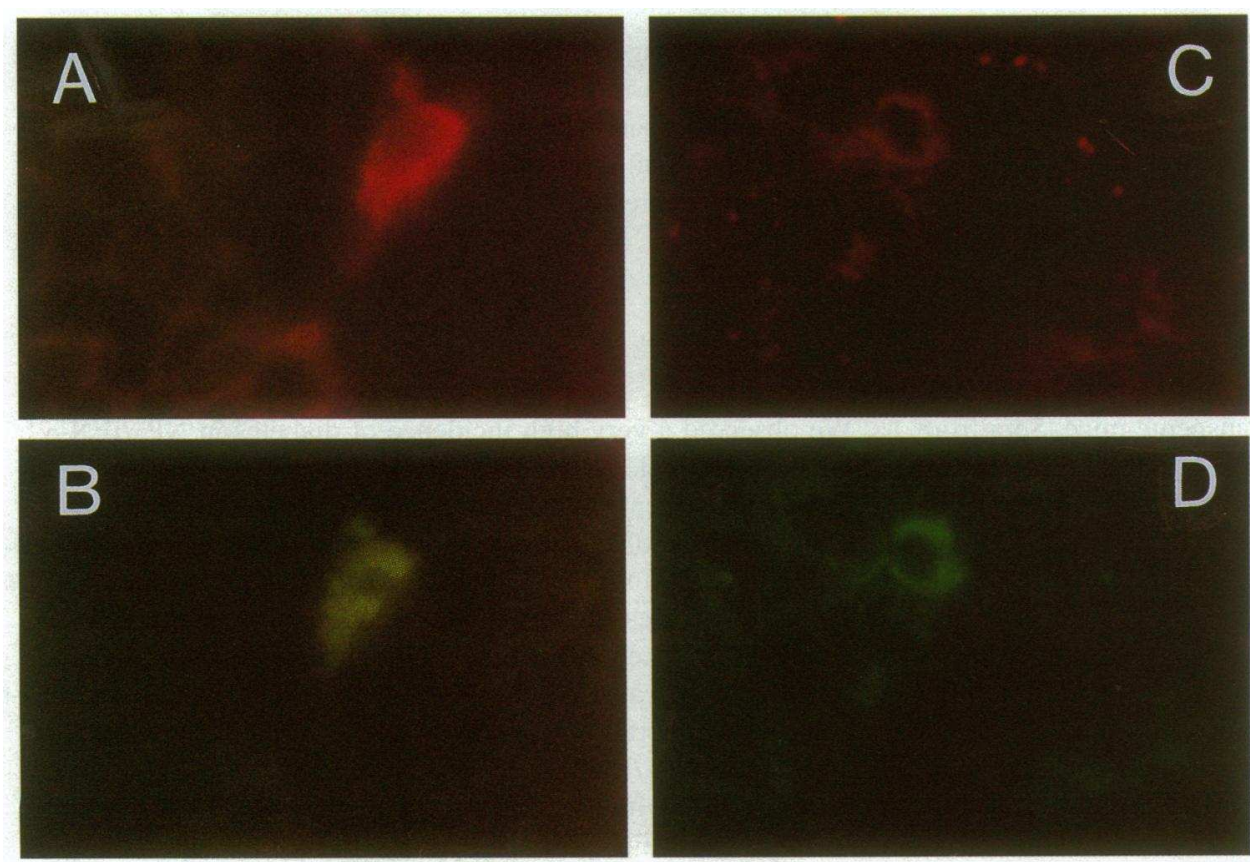

Figure 6. Double immunofluorescence studies showed that macrophages stained with $\mathrm{F} 4 / 80$ antibody $(A)$ expressed B7-1 molecules $(B)$ in the pancreas of a 3-mo-old NP + IFN$\gamma^{+}$mouse. Some B lymphocytes stained with anti-B220 antibody $(C)$ also expressed B7-1 molecules $(D)$ $(\times 1,000)$. In addition to scattered double-positive cells, many singlepositive cells were present. Doublepositive cells were observed in the pancreas of $\mathrm{GP}^{+} / \mathrm{IFN}-\gamma^{+}$mice as well. 
may play a role in the phenotypic differences between $\mathrm{NP}^{+} /$ IFN- $\gamma^{+}$and $\mathrm{GP}^{+} / \mathrm{IFN}-\gamma^{+}$mice. However, possible thymic expression of GP antigen would not contribute to the lower level of CTL activity and low incidence of diabetes in $\mathrm{GP}^{+} / \mathrm{IFN}-\gamma^{+}$ mice because GP was not expressed in the thymus of the RIPLCMV-GP line 34-20 (15).

The development of CTL and spontaneous diabetes in LCMV/IFN- $\gamma$ double transgenic mice contrasts with results of TNF- $\alpha$ transgenic mice, which did not develop spontaneous diabetes themselves or when crossed with mice expressing LCMV antigens (16). The induction of CTL responses to viral antigens noted in LCMV/IFN- $\gamma$ mice also contrasts with the observation that IL-2 or IL-6 transgenic mice crossed with RIPLCMV mice did not develop a spontaneous CTL response to viral antigens (17). Similarly, no spontaneous autoimmunity arose in RIP-IL-2 transgenic mice or RIP-IL-2/RIP-K $\mathrm{K}^{\mathrm{b}}$ double transgenic mice (18). Sensitization to islet antigens $\left(K^{b}\right)$ was not directly demonstrated in transgenic mice that expressed $\mathrm{H}$ $2 \mathrm{~K}^{\mathrm{b}}$ and $\mathrm{IL}-2$ in pancreatic $\beta$ cells and also had the $\mathrm{T}$ cell receptor specific for $K^{b}$, although the development of diabetes was accelerated (19). These discrepancies indicate that cytokines differ in their ability to cause specific immune sensitization and emphasize the unique capacity of IFN- $\gamma$ to elicit T cell responses.

The expression of B7-1 on the APC but not on pancreatic islet cells is consistent with the notion that the killing of targets by effector CTL does not require costimulatory signals (20). Transgenic expression of B7-1 molecules on pancreatic $\beta$ islet cells has been reported to confer antigen presenting ability to islet cells $(21,22)$; however, it is not clear if parenchymal cells can express costimulatory molecules physiologically in vivo or if such cells expressing costimulatory molecules are able to present antigen in natural autoimmune disorders or models. In contrast to those models, specific sensitization to self antigens by IFN- $\gamma$ in our system might be related to the expression of costimulatory molecules such as B7-1 on, and their presentation by, APC infiltrating the pancreas of transgenic mice. In this regard, the pathway for the activation of ignorant lymphocytes in this model is different from that postulated by Bottazzo et al. (23) in which epithelial cells express aberrant class II MHC molecules and present self antigens without the help of APC leading to autoimmunity.

The pathway to immunological sensitization to pancreatic LCMV antigens by local production of IFN- $\gamma$ is clearly distinct from the systemic sensitization to LCMV antigens after LCMV infection with diabetes resulting from crossreactivity to the same viral (islet) antigen $(6,7)$. Our system probably involves sensitization of lymphocytes to islet LCMV antigens within nonlymphoid peripheral organs where IFN- $\gamma$ is expressed. However, in related experiments, systemic administration of IFN- $\gamma$ to uninfected RIP-LCMV mice failed to elicit diabetes (7). The discrepancy between these results and our data could reflect a difference in the concentration or duration of IFN- $\gamma$ experienced locally or a hierarchy effect mediated by a general suppression of lymphoid tissues, rendering peripheral inflammatory responses unlikely. Recent studies using double transgenic mice expressing both IFN- $\gamma$ and human CD4 in the pancreatic $\beta$ cells failed to demonstrate humoral autoimmunity directed to the CD4 molecule (24). As a Th1-promoting, Th2inhibiting cytokine, the effect of production of IFN- $\gamma$ would favor a cellular immune response rather than a humoral response
(25), which could explain the absence of humoral response to CD4. This would also explain the absence of anti-LCMV antibody in $\mathrm{NP}^{+} / \mathrm{IFN}-\gamma^{+}$and $\mathrm{GP}^{+} / \mathrm{IFN}-\gamma^{+}$mice in our system.

Our results, the striking demonstration of spontaneous CTL generation in mice with a normal, unmanipulated $\mathrm{T}$ cell repertoire, suggest that one mechanism of autoimmunity may result from local activation of lymphocytes specific for self antigens but ignorant of those antigens because of their location on nonAPC. These lymphocytes become activated by alteration of the pancreatic environment such as elicitation of cytokines. Those lymphocytes corresponding to self constituents would then be able to respond to their respective antigens and initiate an autoimmune response which could be perpetuated by their proliferation within the tissue, subsequent cellular damage, and liberation of other sequestered antigens allowing the amplification of the anti-self response. The acceleration of diabetes observed in our double transgenic mice could reflect the ability of a single, well-represented antigen to intensify this process.

\section{Acknowledgments}

We are grateful to S. Zhu and J. Dockter for their excellent technical assistance. We thank H. Fox for critical reading and P. Minik for editorial assistance.

M. Lee was supported by a fellowship from the Multiple Sclerosis Society (FA 1007-A-1), and M. von Herrath was supported by a fellowship from the Juvenile Diabetes Foundation (393357). N. Sarvetnick was supported by a career development award from the Juvenile Diabetes Foundation. This work was supported by grants from the National Institutes of Health (HD-29764 and HL-48728 to N. Sarvetnick and AGO4342 to M. B. A. Oldstone). This is manuscript no. 8590-NP from The Scripps Research Institute.

\section{References}

1. Kaufman, D. L., M. Clare-Salzler, J. Tian, T. Forsthuber, G. S. P. Ting, P. Robinson, M. A. Atkinson, E. E. Sercarz, A. J. Tobin, and P. V. Lehmann. 1993. Spontaneous loss of T-cell tolerance to glutamic acid decarboxylase in murine insulin-dependent diabetes. Nature (Lond.). 366:69-75.

2. Tisch, R., X.-D. Yang, S. M. Singer, R. S. Libiau, L. Fugger, and H. O. McDevitt. 1993. Immune response to glutamic acid decarboxylase correlates with insulitis in non-obese diabetic mice. Nature (Lond.). 366:72-75.

3. Harrison, L. C., M. Honeyman, H. J. Deaizpurua, R. S. Schmidli, P. G. Colman, B. D. Tait, and D. S. Cram. 1993. Inverse relation between humoral and cellular immunity to glutamic acid decarboxylase in subjects at risk of insulindependent diabetes. Lancet. 341:1365-1369.

4. Sarvetnick, N., D. Liggitt, S. L. Pitts, S. E. Hansen, and T. A. Stewart. 1988. Insulin-dependent diabetes mellitus induced in transgenic mice by ectopic expression of class II MHC and interferon-gamma. Cell. 52:773-782.

5. Sarvetnick, N., J. Shizuru, D. Liggitt, L. Martin, B. McIntyre, A. Gregory, T. Parslow, and T. Stewart. 1990. Loss of pancreatic islet tolerance induced by $\beta$-cell expression of interferon- $\gamma$. Nature (Lond.). 346:844-847.

6. Oldstone, M. B. A., M. Nerenberg, P. Southern, J. Price, and H. Lewicki. 1991. Virus infection triggers insulin-dependent diabetes mellitus in a transgenic model: role of anti-self (virus) immune response. Cell. 65:319-331.

7. Ohashi, P. S., S. Oehen, K. Buerki, H. Pircher, C. T. Ohashi, B. Odermatt, B. Malissen, R. M. Zinkernagel, and H. Hengartner. 1991. Ablation of "tolerance" and induction of diabetes by virus infection in viral antigen transgenic mice. Cell. 65:305-317.

8. Razi-Wolf, Z., G. J. Freeman, F. Galvin, B. Benacerraf, L. Nadler, and H. Reiser. 1992. Expression and function of the murine B7 antigen, the major costimulatory molecule expressed by peritoneal exudate cells. Proc. Natl. Acad. Sci. USA. 89:4210-4214.

9. Klavinskis, L. A., L. Whitton, and M. B. A. Oldstone. 1989. Molecular engineered vaccine which expresses an immunodominant $\mathrm{T}$-cell epitope induces cytotoxic $\mathrm{T}$ lymphocytes that confer protection from lethal virus infection. $J$. Virol. 63:4311-4316.

10. Reiser, H., G. Freeman, Z. Razi-Wolf, C. D. Gimmi, B. Benacerraf, and L. M. Nadler. 1992. Murine B7 antigen provides an efficient costimulatory signal 
for activation of murine $\mathrm{T}$ lymphocytes via the $\mathrm{T}$-cell receptor/CD3 complex. Proc. Natl. Acad. Sci. USA. 89:271-275.

11. Gu, D., and N. Sarvetnick. 1993. Epithelial cell proliferation and islet neogenesis in IFN- $\gamma$ transgenic mice. Development (Camb.). 11:33-46.

12. Gu, D., M.-S. Lee, T. Krahl, and N. Sarvetnick. 1994. Transitional cells in the regenerating pancreas. Development (Camb.). 120:1873-1881.

13. Whitton, J. L., P. J. Southern, and M. B. A. Oldstone. 1988. Analysis of the cytotoxic $\mathrm{T}$ lymphocyte responses to glycoprotein and nucleoprotein components of lymphocytic choriomeningitis virus. Virology. 162:321-327.

14. Lee, M.-S., L. Wogensen, J. Shizuru, M. B. A. Oldstone, and N. Sarvetnick 1994. Pancreatic islet production of murine interleukin-10 does not inhibit immune-mediated tissue destruction. J. Clin. Invest. 93:1332-1338.

15. von Herrath, M., J. Dockter, and M. B. A. Oldstone. 1994. Role of the thymus in virus-induced insulin-dependent diabetes mellitus in a transgenic model Immunity. 1:231-242.

16. Higuchi, Y., P. Herrera, P. Muniesa, P. Huarte, D. Belin, P. Ohashi, P Aichele, L. Orci, J.-D. Vassalli, and P. Vassalli. 1992. Expression of a tumo necrosis factor a transgene in murine pancreatic $\beta$ cells results in severe and permanent insulitis without evolution towards diabetes. J. Exp. Med. 176:17191731.

17. von Herrath, M. G., J. Allison, J. F. A. P. Miller, and M. B. A. Oldstone 1995. Focal expression of interleukin-2 does not break unresponsiveness to "self" (viral) antigen expressed in $\beta$ cells but enhances development of autoimmune disease (diabetes) after initiation of anti-self immune response. J. Clin. Invest. 95:477-485.

18. Allison, J., L. Malcolm, N. Chosich, and J. F. A. P. Miller. 1992. Inflam- mation but not autoimmunity occurs in transgenic mice expressing constitutive levels of interleukin-2 in islet $\beta$ cells. Eur. J. Immunol. 22:1115-1121.

19. Heath, W. R., J. Allison, M. W. Hoffmann, G. Schonrich, G. Hammerling, B. Arnold, and J. F. A. P. Miller. 1992. Autoimmune diabetes as a consequence of locally produced interleukin-2. Nature (Lond.). 359:547-549.

20. Harding, F. A., and J. P. Allison. 1993. CD-28-B7 interactions allow the induction of $\mathrm{CD} 8+$ cytotoxic lymphocytes in the absence of exogenous help. $J$. Exp. Med. 177:1791-1796.

21. Harlan, D. M., H. Hengartner, M. L. Huang, Y.-H. Kang, R. Abe, R. W Moreadith, H. Pircher, G. S. Gray, P. S. Ohashi, G. J. Freeman, et al. 1994. Mice expressing both B7-1 and viral glycoprotein on pancreatic beta cells along with glycoprotein-specific transgenic $\mathrm{T}$ cells develop diabetes due to a breakdown of T-lymphocyte unresponsiveness. Proc. Natl. Acad. Sci. USA. 91:3137-3141.

22. Guerder, S., D. E. Picarella, P. S. Linsley, and R. A. Flavell. 1994 Costimulator B7-1 confers antigen-presenting-cell function to parenchymal tissue and in conjunction with tumor necrosis factor- $\alpha$ leads to autoimmunity in transgenic mice. Proc. Natl. Acad. Sci. USA. 91:5138-5142.

23. Bottazzo, G. F., R. Pujoll-Borrell, and T. Hanafusa. 1983. HLA-DR expression and antigen presentation in induction of endocrine autoimmunity. Lancet. ii: $1115-1118$.

24. Martin, L., M. Mora-Worms, C. Lucas, C. Reynolds, and T. A. Stewart. 1993. An evaluation of mechanisms by which tolerance to organ-specific antigens is lost using a transgenic mouse model. J. Immunol. 150:1234-1243.

25. Gajewski, T. F., and F. W. Fitch. 1988. Anti-proliferative effect of IFNgamma in immune regulation. I. IFN-gamma inhibits the proliferation of Th2 but not Th1 murine helper T lymphocyte clones. J. Immunol. 140:4245-4252. 